\title{
The SCOPSCO drilling project recovers more than 1.2 million years of history from Lake Ohrid
}

\author{
B. Wagner ${ }^{1}$, T. Wilke ${ }^{2}$, S. Krastel ${ }^{3}$, G. Zanchetta ${ }^{4}$, R. Sulpizio ${ }^{5}$, K. Reicherter ${ }^{6}$, M. J. Leng ${ }^{7}$,

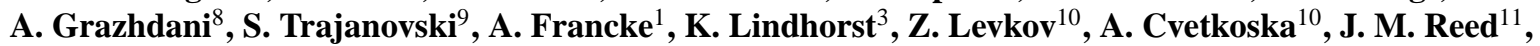

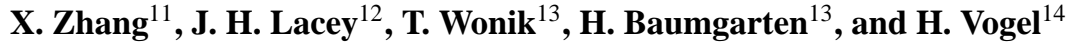 \\ ${ }^{1}$ Institute of Geology and Mineralogy, University of Cologne, Zülpicher Str. 49a, 50674 Cologne, Germany \\ ${ }^{2}$ Department of Animal Ecology \& Systematics, Justus Liebig University, Heinrich-Buff-Ring 26-32, 35392 \\ Giessen, Germany \\ ${ }^{3}$ Institute of Geosciences, Christian-Albrechts-Universität zu Kiel, Otto-Hahn-Platz 1, 24118 Kiel, Germany \\ ${ }^{4}$ Dipartimento di Scienze della Terra, University of Pisa, via S. Maria 53, 56126 Pisa, Italy \\ ${ }^{5}$ Dipartimento di Scienze della Terra e Geoambientali, University of Bari, via Orabona 4, 70125 Bari, Italy \\ ${ }^{6}$ Institute of Neotectonics and Natural Hazards, RWTH Aachen, Lochnerstraße 4-20, 52056 Aachen, Germany \\ ${ }^{7}$ Department of Geology, University of Leicester, Leicester LE1 7RH, UK \& NERC Isotope Geosciences \\ Laboratory (NIGL), British Geological Survey, Keyworth, Nottingham, NG12 5GG, UK \\ ${ }^{8}$ Institute of Geosciences \& Energy, Water \& Environment, Polytechnic University of Tirana, Albania \\ ${ }^{9}$ Hydrobiological Institute Ohrid, Naum Ohridski 50, 6000 Ohrid, Republic of Macedonia \\ ${ }^{10}$ Institute of Biology, Faculty of Natural Sciences, Gazi Baba bb, 1000 Skopje, Republic of Macedonia \\ ${ }^{11}$ Department of Geography, Environment and Earth Sciences, University of Hull, Cottingham Road, Hull HU6 \\ 7RX, UK \\ ${ }^{12}$ Department of Geology, University of Leicester, Leicester LE1 7RH, UK \\ ${ }^{13}$ Leibniz Institute for Applied Geophysics, Stilleweg 2, 30655 Hanover, Germany \\ ${ }^{14}$ Institute of Geological Sciences \& Oeschger Centre for Climate Change Research, University of Bern, \\ Baltzerstrasse 1+3, 3012 Bern, Switzerland \\ Correspondence to: B. Wagner (wagnerb@uni-koeln.de)
}

Received: 3 February 2014 - Revised: 26 March 2014 - Accepted: 27 March 2014 - Published: 29 April 2014

Abstract. The Scientific Collaboration on Past Speciation Conditions in Lake Ohrid (SCOPSCO) project is an international research initiative to study the influence of major geological and environmental events on the biological evolution of lake taxa. SCOPSCO drilling campaigns were carried out in 2011 and 2013 . In 2011 we used gravity and piston coring at one of the five proposed drill sites, and in 2013 we undertook deep drilling with the Deep Lake Drilling System (DLDS) of Drilling, Observation and Sampling of the Earth's Continental Crust (DOSECC). In April and May 2013, a total of $2100 \mathrm{~m}$ sediments were recovered from four drill sites with water depths ranging from 125 to $260 \mathrm{~m}$. The maximum drill depth was $569 \mathrm{~m}$ below the lake floor in the centre of the lake. By retrieving overlapping sediment sequences, $95 \%$ of the sediment succession was recovered. Initial data from borehole logging, core logging and geochemical measurements indicate that the sediment succession covers $>1.2$ million years (Ma) in a quasi-continuous sequence. These early findings suggest that the record from Lake Ohrid will substantially improve the knowledge of long-term environmental change and short-term geological events in the northeastern Mediterranean region, which forms the basis for improving understanding of the influence of major geological and environmental events on the biological evolution of endemic species. 


\section{Introduction and goals}

The Scientific Collaboration on Past Speciation Conditions in Lake Ohrid (SCOPSCO) project is an international research initiative to study the influence of major geological and environmental events on the biological evolution of aquatic taxa. The target site is Lake Ohrid, considered the oldest lake in continuous existence in Europe, and which contains more than 200 endemic species. The recovery of long sediment sequences from Lake Ohrid enables us to obtain information about the age and origin of the lake, and helps to improve our understanding of the regional climatic and environmental evolution including the history of Italian volcanic eruptions.

Lake Ohrid is $\sim 30 \mathrm{~km}$ long, $15 \mathrm{~km}$ wide, covers an area of $358 \mathrm{~km}^{2}$, and is located at an altitude of $693 \mathrm{~m}$ above sea level (a.s.1.) between Albania and Macedonia on the Balkan Peninsula (Fig. 1). The lake has a maximum water depth of $289 \mathrm{~m}$ and a volume of $55.4 \mathrm{~km}^{3}$. The total inflow of water can be estimated to $37.9 \mathrm{~m}^{3} \mathrm{~s}^{-1}$, with ca. $25 \%$ originating from direct precipitation and $25 \%$ from riverine inflow. About $50 \%$ of the total inflow derives from karst aquifers, of which ca. $8 \mathrm{~m}^{3} \mathrm{~s}^{-1}$ are believed to come from Lake Prespa (Wagner et al., 2010, and references therein). Including Lake Prespa, the total catchment covers an area of $2393 \mathrm{~km}^{2}$. Evaporation $(40 \%)$ and the main outflow, the river Crni Drim (60\%), balance the water budget of Lake Ohrid. Due to its large water volume and low nutrient availability, Lake Ohrid is highly oligotrophic today (e.g. Wagner et al., 2010). The surface water has a specific conductivity of $\sim 200 \mu \mathrm{S} \mathrm{cm}^{-1}$ and a $\mathrm{pH}$ of 8.4 (Matter et al., 2010).

Lake Ohrid is renowned for having an outstanding degree of biodiversity for several groups of organisms, including 212 described endemic species. Endemic species are found in several groups, including bacteria, macrophytes, diatoms, and almost all animal groups such as crustacea, molluscs and fish (Albrecht and Wilke, 2008). There are very few lakes worldwide that contain species with this degree of endemism; examples include lakes Baikal, Tanganyika, Victoria and Malawi. However, all these lakes have a much larger surface area, meaning that Lake Ohrid is the most diverse lake in the world when the number of endemic species is related to surface area (Albrecht and Wilke, 2008). This intriguing characteristic contributed significantly to the establishment of Lake Ohrid as UNESCO World Heritage Site in 1979.

Lake Ohrid is considered to be the oldest lake in Europe and is one of the very few ancient lakes on earth that has likely existed continuously for more than $1 \mathrm{Ma}$. Geological studies suggest that the lake basin formed during the final phases of Alpine orogeny in an approximately N-S trending graben structure between ca. 10 and $2 \mathrm{Ma}$ (cf. Lindhorst et al., 2014). Molecular clock analyses of several endemic species flocks (i.e. groups of closely related species) indicate

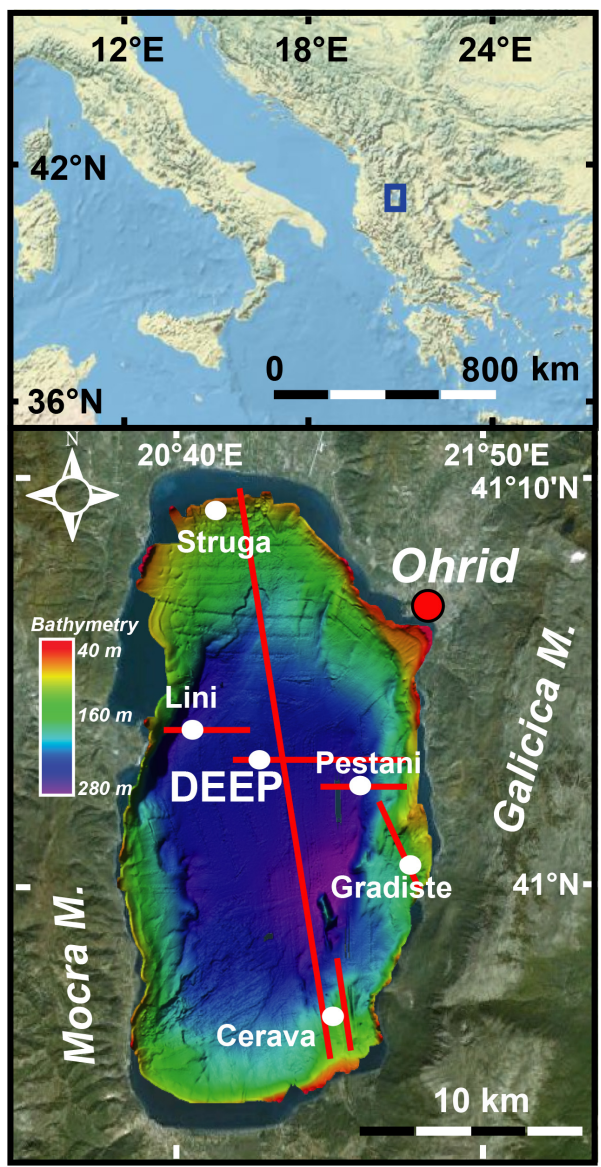

Figure 1. Topographic and bathymetric map of Lake Ohrid on the Balkan Peninsula. ICDP coring sites are indicated by white dots. The red lines indicate the locations of seismic profiles shown in Figs. 2, 3 and 4.

that Lake Ohrid is probably 1.5 to 3 Ma old (Trajanovski et al., 2010).

Previous sedimentary records from Lake Ohrid are up to ca. $15 \mathrm{~m}$ long and span the last glacial/interglacial cycle with some minor hiatuses. These records indicate that Lake Ohrid sediments contain information on long- and shortterm climate change in this region (e.g. Vogel et al., 2010a; Wagner and Wilke, 2011). Other terrestrial records spanning more than $1 \mathrm{Ma}$ are rare from the northern Mediterranean region. The most prominent study is likely the pollen record from Tenaghi Philippon, which covers the last ca. 1.35 Ma (Tzedakis et al., 2006). Continuous marine records of equivalent age are also rare and often analysed at too low temporal resolution (e.g. Kroon et al., 1998) to reliably reconstruct short-term events. In addition to generating proxy data on long- and short-term environmental change, our preliminary studies also revealed that Lake Ohrid is a distal archive of the activity of Italian volcanoes. Its sediments comprise ca. 10 tephra and cryptotephra (i.e. non-visible tephra) layers in the last ca. $140 \mathrm{ka}$. These volcanic event 
Table 1. SCOPSCO drill sites.

\begin{tabular}{lrrrrrrl}
\hline Site & $\begin{array}{r}\text { Water } \\
\text { depth }(\mathrm{m})\end{array}$ & $\begin{array}{c}\text { \# of holes } \\
\text { (planned) }\end{array}$ & $\begin{array}{r}\text { Total drill } \\
\text { metres }(\mathrm{m})\end{array}$ & $\begin{array}{r}\text { Total } \\
\text { recovery }(\mathrm{m})\end{array}$ & $\begin{array}{r}\text { Deepest drill } \\
\text { depth (m b.l.f.) }\end{array}$ & $\begin{array}{r}\text { Length of composite } \\
\text { record * }(\mathrm{m})\end{array}$ & Remarks \\
\hline DEEP & 243 & $6(2)$ & 2088.71 & 1526.06 & 568.92 & $544.88(95.77 \%)$ & spot coring \\
Cerava & $119 / 131$ & $2(2)$ & 175.71 & 172.20 & 90.48 & $87.86(97.10 \%)$ & site on a slope \\
Gradište & 131 & $3(2)$ & 327.35 & 224.46 & 123.41 & $114.07(92.43 \%)$ & \\
Peštani & 262 & $1(0)$ & 194.50 & 177.90 & 194.50 & $177.90(91.45 \%)$ & \\
Lini & 260 & $1(2)$ & 10.08 & 10.08 & 10.08 & $10.08(100.00 \%)$ & drilled in 2011 \\
Struga & 0 & $0(2)$ & 0 & 0 & 0 & 0 & skipped \\
\hline
\end{tabular}

* Composite field recovery is estimated based on field depths and magnetic susceptibility measurements.

layers provide information on ash dispersal from the prominent volcanic regions in Italy and contribute significantly to the construction of a robust chronology by comparison with other dated records in the region using tephrochronological cross-correlation of geochemical fingerprints (Sulpizio et al., 2010; Caron et al., 2010; Vogel et al., 2010b; Damaschke et al., 2013). In addition, analysis of Lake Ohrid sediments will generate information on tectonic events. The lake is located in a highly active seismic zone with frequent earthquakes (e.g. Muço et al., 2002; NEIC database, USGS), and the lacustrine sediments on the subaquatic slopes are subject to mass wasting and seismite formation (Wagner et al., 2008; Reicherter et al., 2011; Lindhorst et al., 2012). Studies from other lakes and marine basins have shown that these mass-wasting deposits can be used to reconstruct the longterm earthquake history of a region (e.g. Schnellmann et al., 2002; Beck et al., 2012).

Despite uncertainties in age estimation, its likely continuous existence over more than $1 \mathrm{Ma}$ makes Lake Ohrid an extant hotspot of evolution and an evolutionary reservoir enabling relict species to survive (Albrecht and Wilke, 2008). These outstanding characteristics allowed Lake Ohrid to become one of the target sites within the scope of the International Continental Scientific Drilling Program (ICDP). The deep drilling of Lake Ohrid has four major aims: (i) to obtain precise information about the age and origin of the lake, (ii) to unravel the regional seismotectonic history including effects of major earthquakes and associated mass-wasting events, (iii) to obtain a continuous record containing information on Quaternary volcanic activity and climate change in the central northern Mediterranean region, and (iv) to evaluate the influence of major geological events on evolution and the generation of the observed extraordinary degree of endemic biodiversity.

\section{Site selection}

The site selection for the deep drilling project was based on hydro-acoustic surveys carried out between 2004 and 2008 . Multichannel seismic data were collected using a Mini GI Air Gun $(0.25 \mathrm{~L}$ in 2007 and $0.1 \mathrm{~L}$ in 2008) and a 16-channel
$100 \mathrm{~m}$ long streamer, complemented by parametric sediment echosounder profiles (SES-96 light in 2004 and SES 2000 compact in 2007 and 2008, Innomar Co.). The theoretical vertical resolution of both types of seismic data can be estimated to be $2 \mathrm{~m}$ for the Mini GI gun and $0.2 \mathrm{~m}$ for the Innomar data.

Based on a dense grid of multichannel seismic data $(\sim 500 \mathrm{~km}$ total length) and sediment echosounder profiles ( $>900 \mathrm{~km}$ total length), five drill sites were originally proposed (Fig. 1; Table 1). They range from 80 to $260 \mathrm{~m}$ water depth and had target drilling depths between 20 and $680 \mathrm{~m}$.

The "DEEP" site is located in the central basin of Lake Ohrid in $\sim 250 \mathrm{~m}$ water depth. This master site is well suited to address most of our key research questions (Table 1). The seismic data from the central basin show a rough basement topography with numerous highs and lows (Figs. 2 and 3). The basement lows are characterized by onlap fills and therefore suggested possible recovery of the longest records. The DEEP site is located in a basement depression with an estimated maximum sediment fill of $680 \mathrm{~m}$ (Fig. 3). Seismic data show undisturbed sediments without unconformities or erosional features, thus suggesting that a continuous sediment record of maximum age and free of major hiatuses could be recovered. Strong multiples, however, mask the lower part of the sedimentary succession.

The "Struga" site is located close to the northern shore of Lake Ohrid (Fig. 1). It is the shallowest ( $80 \mathrm{~m}$ water depth) of all the sites. The objectives of this site are to investigate changes in the hydrological regime, to obtain information on lake level fluctuations, and potentially to obtain macrofossils for a cross-validation with the results obtained from molecular clock analyses. The intention to drill at the Struga site in the northern part of the lake was abandoned for logistical reasons during the drilling campaign. Instead, a new site was selected in the eastern part of the lake. This "Peštani" site (Fig. 1) had a water depth of $260 \mathrm{~m}$ and was chosen with the aim of reaching sediments deposited directly above the bedrock at ca. $200 \mathrm{~m}$ below lake floor (b.l.f.; Fig. 4).

The "Cerava" site (Figs. 1 and 4) is located on a lake terrace in $125 \mathrm{~m}$ water depth close to the southern shore of Lake Ohrid, $2-3 \mathrm{~km}$ off the southern feeder spring area and Cerava River, which are the main tributaries to Lake Ohrid. Several 


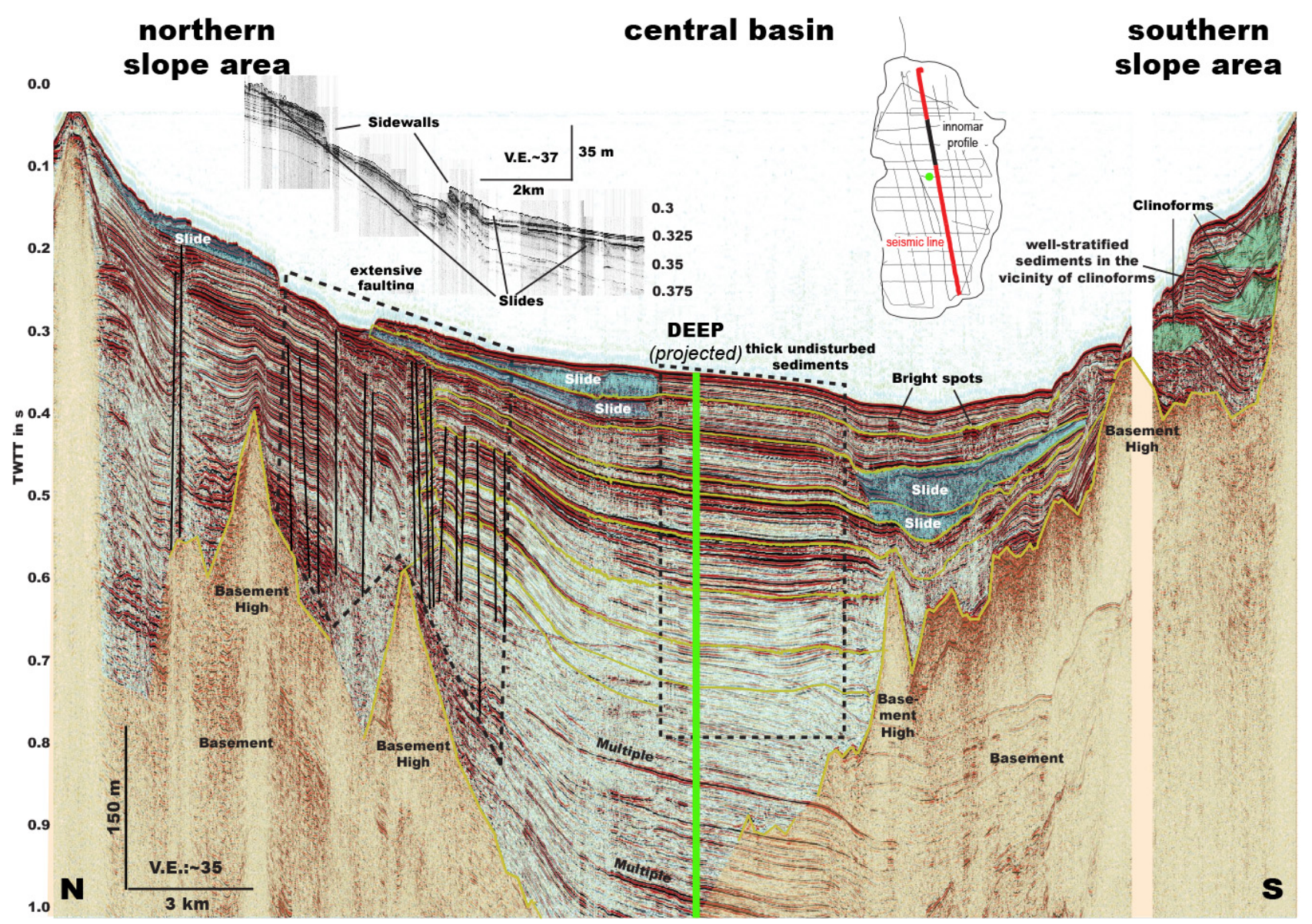

Figure 2. Seismic profile crossing Lake Ohrid in N-S direction. The central basin shows thick undisturbed sediments, which were drilled at the DEEP site. The DEEP site is about $1 \mathrm{~km}$ to the west of the seismic line. Other prominent features include faults, slides, clinoforms and bright spots. See Fig. 1 for location.

clinoforms in the seismic data reflect the development of terraces, which are linked to lake-level fluctuations. The main objective of this site is to reconstruct these variations. In addition, data from this core will be used to support our interpretation of tectonic activities and related mass-movement events.

The "Gradište" site (Figs. 1 and 4) is located in $130 \mathrm{~m}$ water depth close to the eastern margin of the lake in the hanging wall of a major active lake-bounding normal fault. The bathymetry reveals a steep west-dipping major fault associated with a small graben on the lake floor, which suggests recent activity of this fault. The Gradište site is also characterized by high inflow from sublacustrine karstic springs and constitutes the most important hotspot of endemic biodiversity in the lake. Macrofossils from this site are expected to best reflect the evolutionary history of invertebrates and plants and should allow us to test the role of sublacustrine springs in generating and maintaining biodiversity.

The "Lini" site (Figs. 1 and 4) is off the Lini Peninsula in $260 \mathrm{~m}$ water depth close to the western shore of Lake Ohrid. This locality was selected to study fault activity on the west- ern basin bounding faults. Seismic profiles across the western coast show that the steepest gradient in front of the Lini Peninsula is due to active scarps of eastwards-dipping normal faults. The tectonic setting is comparable to the Gradište site with a set of active antithetic faults.

\section{Coring results and borehole logging}

Coring was originally planned for summer 2011 using Drilling, Observation and Sampling of the Earth's Continental Crust's (DOSECC) Deep Lake Drilling System (DLDS). Although this was postponed, a coring campaign using UWITEC (Austria) equipment was carried out in June 2011 in order to recover a $20 \mathrm{~m}$ long sediment sequence proposed for the Lini site and also surface sediment cores from the DEEP site. A gravity corer was used to obtain the undisturbed surface sediments, and deeper sediments were recovered with a piston corer. A re-entry cone, which was positioned on the lake bed, and extension rods of $2 \mathrm{~m}$ length controlled the exact release of the piston to ensure retrieval of a 


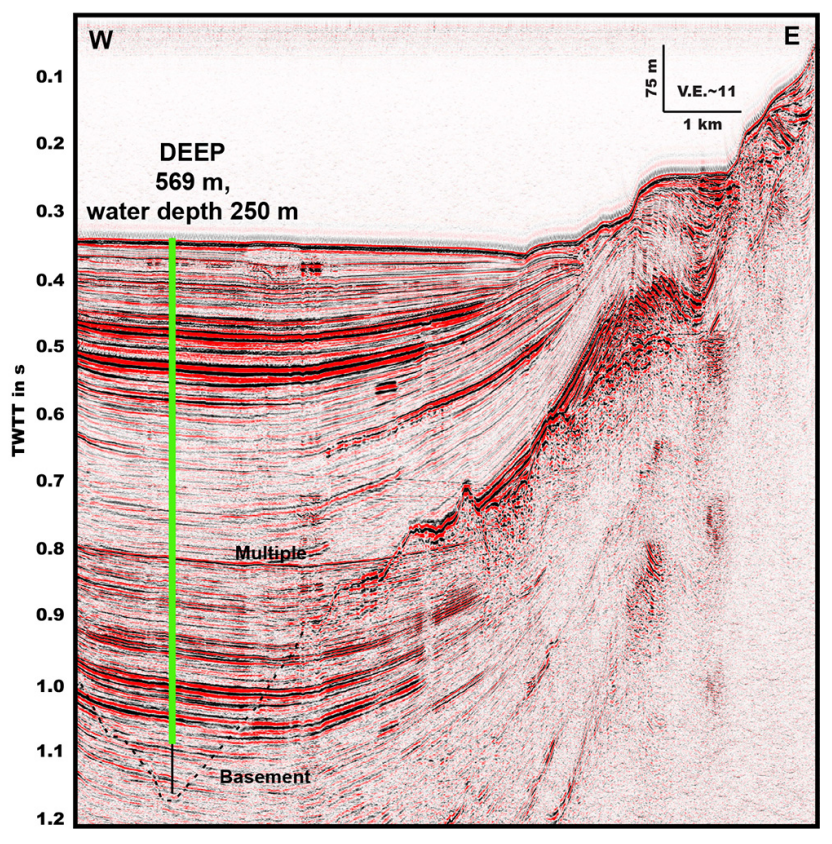

Figure 3. Seismic profile crossing the DEEP site in W-E direction (only Macedonian part of Lake Ohrid due to missing Albanian permissions during the 2007 survey). See Fig. 1 for location. The green line in the seismic profile indicates the approximate maximum depth of cores recovered from DEEP site, whilst the black line indicates the originally proposed target depth.

continuous core sequence. Core recovery at the Lini site was around $100 \%$ including core catcher samples. Core loss or disturbance of sediment between the individual $2 \mathrm{~m}$ segments is therefore regarded as low $(<6 \mathrm{~cm})$. However, bad weather and high waves on Lake Ohrid stopped the coring campaign at ca. $10 \mathrm{~m}$ depth in 2011. At the DEEP site, a $1.6 \mathrm{~m}$ long surface sediment sequence was retrieved.

A fire on the container vessel MV MSC Flaminia, which transported the DLDS from the US to Europe in summer 2012 , caused a second delay for the start of the drilling operations. Finally, drilling started in late March 2013, and by late May 2013 a total of $\sim 2100 \mathrm{~m}$ of sediment had been recovered from Lake Ohrid at four different sites. The SCOPSCO drilling operation is heralded as one of the most successful ICDP lake drilling campaigns ever.

At the DEEP site, six parallel holes were drilled with a maximum sediment depth of $569 \mathrm{~m}$ b.l.f. (Fig. 3). Pelagic sediments characterize the uppermost $430 \mathrm{~m}$ of the sediment column (Fig. 5). Below 430 m b.l.f., shallow water facies became increasingly dominant, including fine-grained material with high organic matter content, coarser sediments with shell remains, and distinct sand layers. Gravel and pebbles hampered penetration deeper than $569 \mathrm{~m}$ b.l.f. In total, $1526 \mathrm{~m}$ of sediment cores were recovered from the six parallel holes at the "DEEP" site. Taking into account sedimentcore overlap, the total composite field recovery amounts to
$95 \%$ (545 m), being higher (99\%) for the uppermost $430 \mathrm{~m}$ (Fig. 5). At the Cerava site, two parallel cores were drilled with a maximum sediment depth of $90.5 \mathrm{~m}$ b.l.f. (Fig. 6). The composite field recovery was ca. $97 \%(88 \mathrm{~m})$. The basal sediments recovered consist of lithified sediments and shell fragments or whole shells. At the Gradište site, three parallel cores were drilled with a maximum sediment depth of $123 \mathrm{~m}$ b.l.f. (Fig. 6). The composite core recovery was $92 \%(114 \mathrm{~m})$. Coarse-grained sediments dominate below $82 \mathrm{~m}$ b.l.f. At the Peštani site only one hole with a maximum sediment depth of $194.5 \mathrm{~m}$ b.l.f. was recovered (Fig. 6). The core recovery was $91 \%(178 \mathrm{~m})$.

At all four drill sites, generation of high-quality continuous downhole logging data comprising spectral gamma ray, magnetic susceptibility (MS), resistivity, dipmeter, borehole televiewer and sonic data was achieved. Additional zerooffset vertical seismic profiling was conducted at the DEEP site. Spectral gamma ray was run through the drill pipe, and thereafter pipes were pulled gradually to maintain the borehole stability. All the other tools were run in about $40 \mathrm{~m}$ long open hole sections.

\section{Preliminary scientific results}

\subsection{Downhole logging}

Downhole logging data at the DEEP site reveal contrasting physical properties in spectral gamma ray (gamma ray, $K, U$, Th), MS, resistivity and seismic velocity ( $v p)$ data. The sediment sequence below $430 \mathrm{~m}$ b.l.f. is characterized by higher gamma ray values (mean: $70 \mathrm{gAPI}$ ) than pelagic sediments above, showing a cyclic alternation of low (20 gAPI) and high (65 gAPI) gamma ray values (Fig. 5).

\subsection{Sedimentological work}

In addition to borehole logging, some data have already been generated from the sediment sequences recovered. The age model and sediment stratigraphy of the $10 \mathrm{~m}$ long sediment sequence recovered from the Lini site in summer 2011 spans the Late Pleistocene to Holocene and contains two masswasting deposits (Wagner et al., 2012). The more significant uppermost mass-wasting deposit is almost $2 \mathrm{~m}$ thick and directly overlies the AD 472/512 tephra. The exact age of this mass-wasting deposit cannot be defined because the tephras from AD 472 and AD 512 indicate geochemical overlapping, and the sediments of Lake Ohrid are not annually laminated. However, the lack of any apparent erosional discordance at the base of the mass-wasting deposit and the small distance to the AD 472/512 tephra imply that the mass-wasting deposit occurred in the early 6th century AD (Wagner et al., 2012). A likely trigger for this mass-wasting event could be a historical earthquake that destroyed the city of Lychnidus (Ohrid). According to historical documents, this earthquake could have occurred at AD 518, AD 526, or AD 527. 

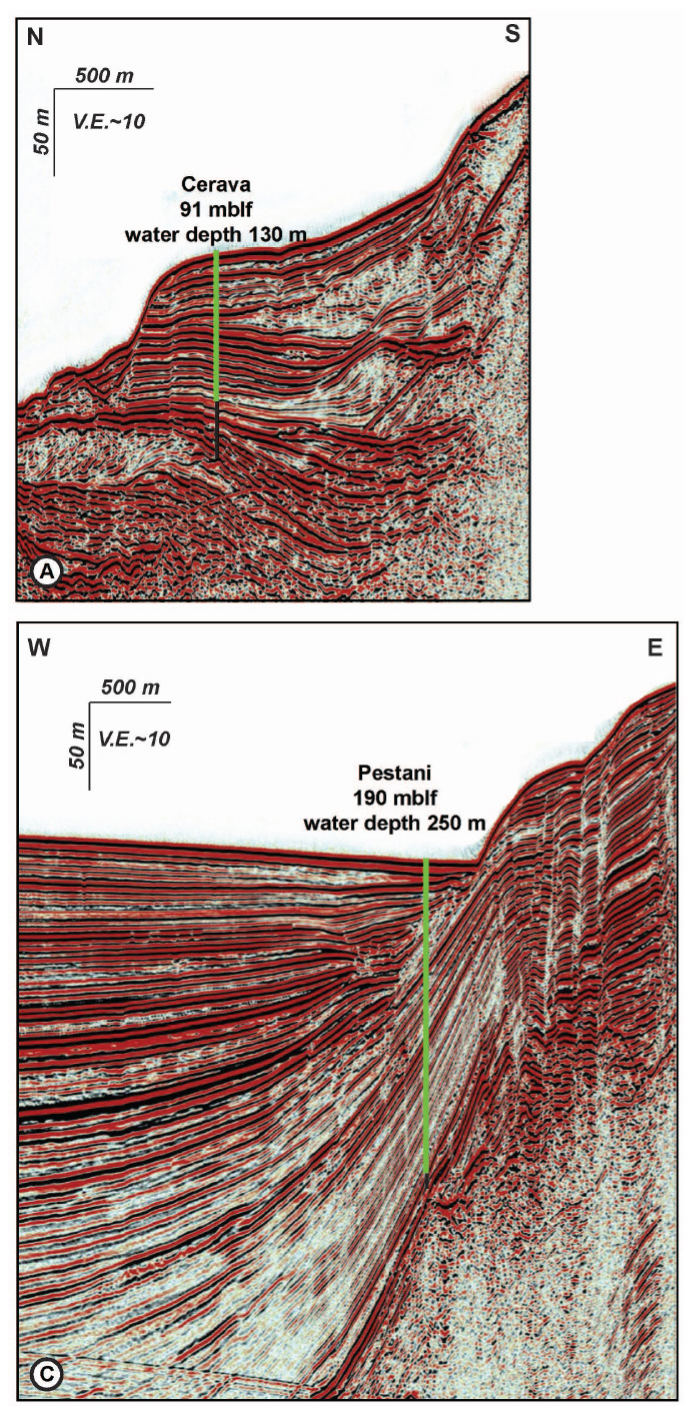
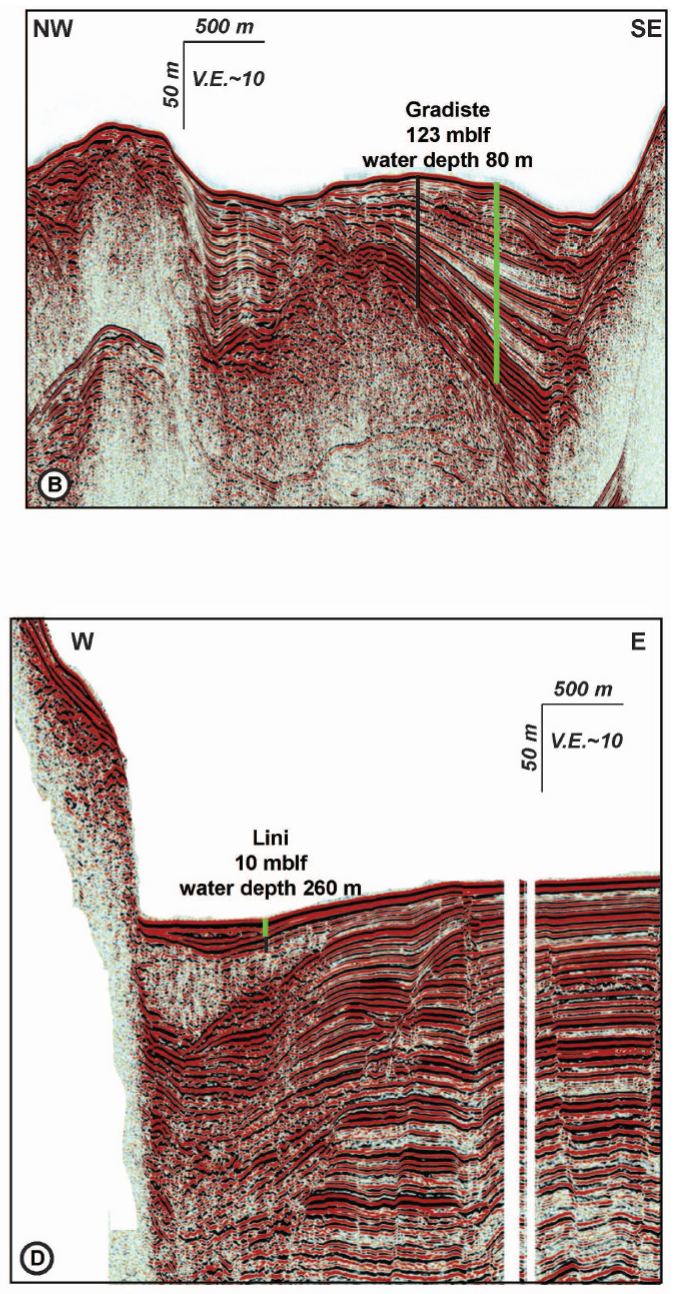

Figure 4. Seismic cross sections at drill sites (A) Cerava, (B) Gradište, (C) Peštani, and (D) Lini. The green line in the individual seismic profiles indicates the approximate maximum depth of cores recovered, whilst the black line indicates the target depth.

Although the sediment sequence from the Lini site is shorter than proposed, the results indicate that one of the main scientific goals of the project - to reconstruct active tectonics and mass wasting (Table 1) - can be achieved.

MS was measured on all cores recovered in summer 2013 using a multi-sensor core logger (MSCL; Geotek, UK) in a field laboratory. Logging started immediately after the transportation of the cores from the drilling platform to the laboratory in order to ensure best possible overlap between individual holes. The volume-specific MS was measured over $10 \mathrm{~s}$ for every $2 \mathrm{~cm}$ of each core section with a whole core loop sensor (internal diameter: $10 \mathrm{~cm}$ ). The data show a pronounced cyclic pattern most likely related to glacial/interglacial cycles and demonstrate the excellent potential of Lake Ohrid for palaeoenvironmental reconstructions (Fig. 5). We also identified a similar cyclic pattern in the seismic data and interpreted them as a climatic signal (Lindhorst et al., 2014). A preliminarily correlation between seismic and MS data using a simple time-depth chart constructed out of available $p$ wave velocity data for the DEEP site allows an optical correlation between the cyclicity of seismic and MS data (Fig. 5), demonstrating the great potential to integrate physical properties, sedimentological and seismic data. Distinct peaks of MS are most likely correlated with the occurrence of tephras or cryptotephras in the sedimentary succession.

Small aliquots of core catcher material from the DEEP site were freeze-dried and homogenized. This material was used for measurements of total carbon (TC) and total inorganic carbon (TIC) using a DIMATOC 200 (DIMATEC Co.). Total organic carbon (TOC) was calculated as the difference between TC and TIC. Studies of the sediment cores recovered 


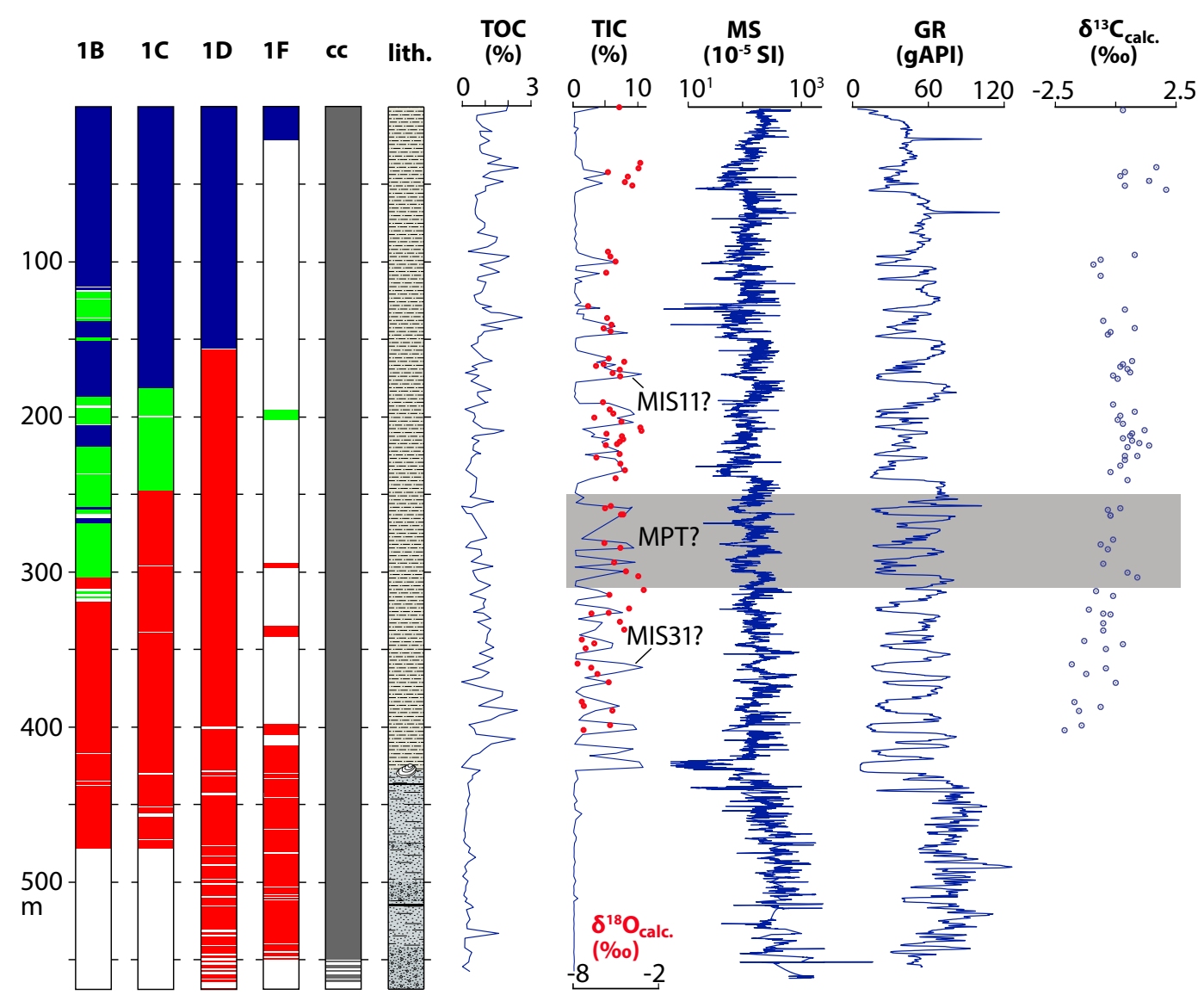

HPC $\square$ XTN $\square$ ALN
composite recovery

园 silty clay or clayey silt

国 gravel, sand, silt, clay

sand, silt, clay

$\boxminus$ peat

bivalve remains

Figure 5. Core recovery and lithology from DEEP site. Colours indicate the different coring tools used for the four parallel holes $1 \mathrm{~B}$, 1C, $1 \mathrm{D}$, and $1 \mathrm{~F}$ with deeper penetration. A hydraulic piston corer (HPC, blue) was used for the recovery of the upper sediment sequences. The relatively soft consistency of these sediments allows penetration of a $3 \mathrm{~m}$ long piston corer by hydraulic pressure. Rotation drill tools were used for the deeper and more consolidated sediments and comprise the extended nose (XTN, green), where the drill bits stand back by about $12 \mathrm{~cm}$ from the core barrel front, and the Alien (ALN, red), where the drill bits are placed directly at the core barrel front. 1A and 1E are not displayed as coring was restricted to surface sediments $(<5 \mathrm{~m})$ using the HPC. The core composite (cc) is based on core correlation of individual holes based on field depth measurements. White parts indicate no core recovery due to gaps. The lithology (lith.), total organic carbon (TOC), total inorganic carbon (TIC), and stable isotope $\left(\delta^{18} \mathrm{O}_{\text {calc. }}\right.$, red dots in the TIC curve, and $\delta^{13} \mathrm{C}_{\text {calc. }}$ to the right) measurements are based on core catcher samples. Magnetic susceptibility (MS) was measured in $2 \mathrm{~cm}$ intervals on a multi-sensor core logger (MSCL) equipped with a whole core loop sensor. Spectral gamma ray (GR) is based on downhole logging data run through the drill pipe with $10 \mathrm{~cm}$ vertical resolution. The grey bar indicates tentatively the Middle Pleistocene transition (MPT). Marine isotope stages (MIS) 11 and 31 are extrapolated from glacial/interglacial changes in TIC contents.

during pre-site surveys between 2005 and 2009 have already shown that TIC is a valuable proxy for short-term and longterm climate change over the last ca. $135 \mathrm{ka}$ (Vogel et al., 2010a; Wagner et al., 2010). TIC is high during interglacials and primarily originates from calcite precipitation. During glacial phases carbonate is almost absent. In the core catcher samples from the DEEP site, very low TIC characterizes the coarser sediments below $430 \mathrm{~m}$ b.l.f. (Fig. 5). This indicates that fluvial conditions prevailed at the onset of the existence of Lake Ohrid and that the clastic detrital matter supplied does not originate from the calcareous Galiçica mountain range to the east of the lake (Fig. 1), where the main inlets are located today. At $430 \mathrm{~m}$ b.l.f. TIC significantly increases upcore to slightly more than $10 \%$. This implies that the lake had established and relatively warm conditions in combination with higher productivity that caused intense calcite precipitation. Between 430 and 315 m b.l.f. TIC, data show distinct high-frequency fluctuations. This can probably be attributed to the dominant $41 \mathrm{ka}$ obliquity cycle prior to $920 \mathrm{ka}$ (Mudelsee and Schulz, 1997; Tzedakis et al., 2006), and the 


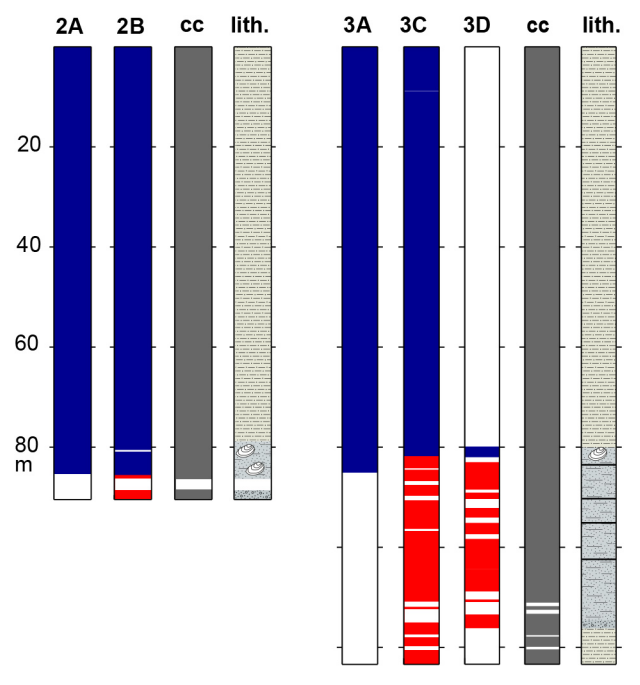

$$
\begin{aligned}
& \text { silty clay or clayey silt } \\
& \text { sand, silt, clay } \\
& \text { gravel, sand, silt, clay } \\
& \square \text { peat } \\
& \text { bivalve remains } \\
& \text { HPC } \\
& \text { XTN } \\
& \text { ALN } \\
& \text { composite recovery }
\end{aligned}
$$

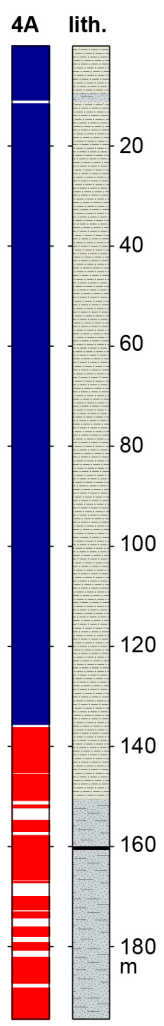

Figure 6. Core recovery and lithology from Cerava (2A and 2B), Gradište (3A, 3C, and 3D), and Peštani (4A) sites. Colours indicate different coring tools used (cf. Fig. 5). White sections in the core composites (cc) of each site indicate no core recovery.

highest TIC peak at ca. $360 \mathrm{~m}$ b.l.f. is tentatively correlated with the Marine Isotope Stage (MIS) 31 (Fig. 5). The sequence between 315 and $250 \mathrm{~m}$ b.l.f. exhibits a decrease in TIC frequency, which probably corresponds to the Middle Pleistocene transition (MPT) between 920 and $640 \mathrm{ka}$. The uppermost $250 \mathrm{~m}$ indicate similar amplitudes in TIC fluctuations, ranging between almost $0 \%$ and $10 \%$, but fluctuating at a lower frequency. This variability can be attributed to $100 \mathrm{ka}$ cycles, which have dominated since $640 \mathrm{ka}$. As interglacial periods should correspond with high TIC, the MIS 11 and MIS 5 sediments in the DEEP site record would occur at ca. 175 and $50 \mathrm{~m}$ b.l.f., respectively (Fig. 5). This is supported by the occurrence of several tephras, which are identical to those identified previously during analysis of cores from presite surveys (Sulpizio et al., 2010; Vogel et al., 2010b). For example, a coarser horizon at $18 \mathrm{~m}$ b.l.f., which is characterized by a maximum in MS and gamma ray data (Fig. 5), corresponds with the Y-5 tephra (Campanian Ignimbrite). This is the most prominent tephra in all other records from Lake Ohrid and was deposited $39.3 \mathrm{ka}$ (e.g. Sulpizio et al., 2010). Numerous peaks in the MS data suggest that the DEEP site will become an outstanding distal record of the activity of Italian eruptive volcanoes and perhaps the "Rosetta Stone" for regional tephrostratigraphy. The low organic matter content in all core catcher samples from the DEEP site sequence, such as reflected by TOC values of $<3 \%$ (Fig. 5), suggests that the lake has had an oligotrophic state throughout its entire existence.

\subsection{Diatom data}

Preliminary diatom data were generated from core catcher samples at ca. $3 \mathrm{~m}$ resolution from two boreholes (1B and 1C) at the DEEP site. Results for $1 \mathrm{C}$ are presented here (Fig. 7). A total of 173 smear slides was prepared, and ca. 100 diatom valves per slide were counted under oil immersion at $\times 1500$ magnification with a Nikon Eclipse 80i light microscope (LM) equipped with a Nikon Coolpix P6000 digital camera. Counts were converted into percentages and displayed using Tilia and TGView v. 2.0.2. (Grimm, 2004). Diatom identification was aided by reference to the taxonomic keys of Krammer and Lange-Bertalot (1986-1991) and dedicated Ohrid and Prespa taxonomic works (Hustedt, 1945; Jurilj, 1954; Levkov et al., 2007, 2012; Cvetkoska et al., 2012). Diatoms were preserved throughout the uppermost $480 \mathrm{~m}$ of the sediment sequence, comprising $122 \mathrm{di}$ atom taxa. Although the benthic group is the most speciesrich ( $60 \%$ of taxa), the sequence above $430 \mathrm{~m}$ b.l.f. is dominated by planktonic species $(>85 \%)$. At the base of the sequence, the initially poor preservation in a coarse substrate (480-430 m b.l.f.) strengthens the interpretation of a shallow water body; the gradual increase in relative abundance of planktonic taxa from 430 to $320 \mathrm{~m}$ b.l.f. probably reflects the initial infilling of the lake basin, with a stable and deep water body thereafter. Major shifts at $430 \mathrm{~m}, 320 \mathrm{~m}, 230 \mathrm{~m}$ and $80 \mathrm{~m}$ b.l.f. are likely to represent key stages of evolution and/or environmental change, the first of which corresponds to the key boundary identified between shallow and deeper lake states. There is clear evidence for evolution within the dominant planktonic genus, Cyclotella. The replacement of C. iris by $C$. fottii/hustedtii, the similar morphological characteristics of which indicate that they are likely to have similar ecological niches, probably represents an excellent example of rapid species turnover. Apparently close correlation with geochemical proxies, and carbonate in particular, suggests that major shifts in diatom-species assemblage composition are driven by glacial/interglacial climate cycles in the latter part of the record. Our previous diatom-based palaeoclimate analysis of sequences spanning the last $134 \mathrm{ka}$, from the last interglacial to present (Wagner et al., 2009; Reed et al., 2010; Cvetkoska et al., 2012), demonstrates the high sensitivity of diatoms to glacial/interglacial and interstadial climate change, driven primarily by temperature-induced productivity shifts. This is supported by modern ecological data, which define the epilimnetic vs. hypolimnetic life habit of dominant planktonic taxa (Allen and Ocevski, 1976). The same suite of dominant taxa prevails in the DEEP sequence above $230 \mathrm{~m}$ b.l.f., giving good modern analogues for future 


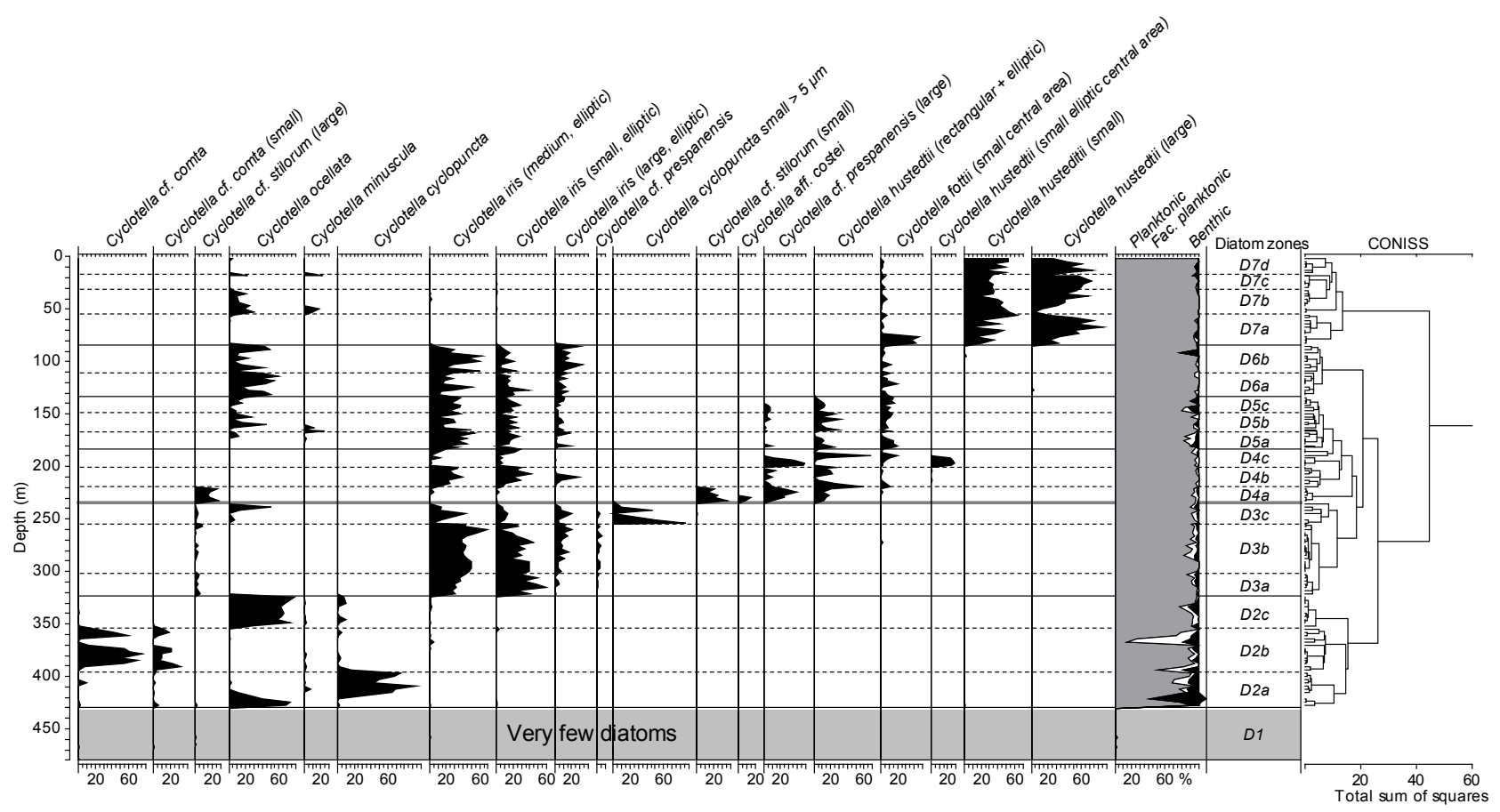

Figure 7. Preliminary diatom data from smear slides of core catcher samples (hole 1C, DEEP site).

palaeoenvironmental reconstruction. Analogues are poor below this depth, underlining the degree to which Quaternary diatom evolution has probably occurred, but the presence of dominant taxa such as Cyclotella iris in oligotrophic fossil assemblages (Krammer and Lange-Bertalot, 1991a) provides a strong baseline from which to reconstruct earlier Quaternary palaeoclimates in the lower record.

\subsection{Stable isotope data}

Stable isotope analysis of carbonate was conducted using sediment aliquots from 69 samples with $>1 \%$ TIC (hole 1B, core catchers). Subsamples were processed to remove organics and measured for stable isotope ratios. The data show $\delta^{18} \mathrm{O}_{\text {calcite }}$ values increasing through the core, ranging between $-7.6 \%$ and $-2.9 \%$, and averaging $-5.2 \% \circ \pm 1.1 \%$ o (Fig. 5), which is most likely the result of greater freshwater input and lower lake-water residence times in earlier interglacials. From modern calibration data sets, $\delta^{18} \mathrm{O}_{\text {calcite }}$ in Lake Ohrid is known to be a function of inflow and evaporation (Leng et al., 2010), so significant positive excursions suggest periods of exceptional aridity and potentially lower lake levels (for example at 50, 210 and $310 \mathrm{mb}$ b.l.f.), which coincide with high TIC phases (interglacial periods). $\delta^{13} \mathrm{C}_{\text {calcite }}$ ranges $(-2.1 \%$ o to $+2.1 \%$, mean $=0.0 \%$ o $\pm 0.8 \%$ o are consistent with the catchment geology providing a major source of inorganic carbon $\left(\delta^{13} \mathrm{C}_{\text {catchment }}=+1 \%\right.$ o enhanced by longer residence times allowing increased exchange with atmospheric $\mathrm{CO}_{2}$ towards the top of the sequence.

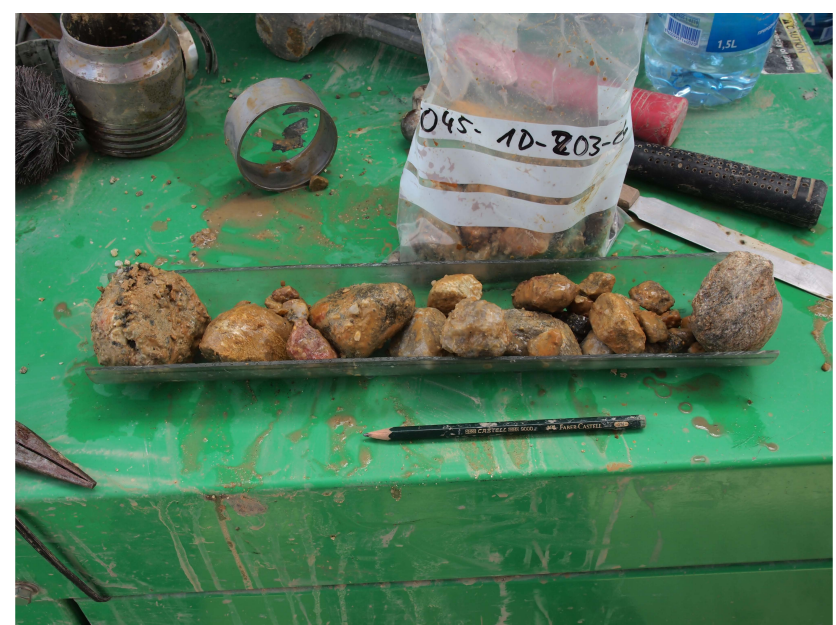

Figure 8. Rounded gravel and pebbles in core catcher material (DEEP site, hole 1D at 569 m b.l.f.) indicate fluvial transportation.

Overall, the patterns seen in borehole logging, MS and core-catcher data imply that the record from the DEEP site covers the entire history of extant Lake Ohrid. Rounded pebbles and gravel from the base of the sediment record (Fig. 8) imply that fluvial sedimentation prevailed in the Lake Ohrid basin before the basin was filled, culminating in the development of the deep modern lake. A stepwise decrease in grain size from the base to $430 \mathrm{~m}$ b.l.f. is attributed to the establishment of lacustrine conditions and increasing lake levels. According to TIC, MS, and borehole gamma ray values, the 
uppermost $430 \mathrm{~m}$ b.l.f. cover probably $>1.2 \mathrm{Ma}$. Major hiatuses or mass-wasting deposits were not observed at this site.

\section{Ongoing and future work}

The sediment cores recovered during the SCOPSCO 2013 field campaign at Lake Ohrid are stored at the University of Cologne, Germany, where core opening, description, documentation, and initial analyses such as MSCL and X-ray fluorescence (XRF) scanning are taking place. The primary focus of current studies is the sediment sequence from the DEEP site. For the XRF scanning, intervals are set to $2.5 \mathrm{~mm}$, which likely provides a decadal resolution. Visual inspection, MS and XRF scanning data will be used to identify horizons with tephras or cryptotephras. Such horizons will be sampled and tephra identification will be carried out (cf. Vogel et al., 2010b; Damaschke et al., 2013). The results combined with palaeomagnetic measurements and chronostratigraphic tuning will be applied to establish an age model.

Subsampling for geochemical, pollen and diatom analyses will be carried out at consistent intervals of $16 \mathrm{~cm}$ on the composite core after core correlation based on visual inspection and XRF data. Based on an estimated average sedimentation rate of ca. $30 \mathrm{yrs} \mathrm{cm}^{-1}$ ( $430 \mathrm{~m}$ sediment column corresponding to ca. $1.2 \mathrm{Ma}$ ), the $16 \mathrm{~cm}$ intervals correspond to a resolution of ca. 500 years. Shorter intervals with higher temporal resolution are envisaged for future studies to investigate, for example, glacial to interglacial transitions or other selected events.

Core opening, description and documentation, and analyses of the Cerava, Gradište and Peštani sediment sequences will be carried out after the DEEP site. Combining the DEEP site with the peripheral drill sites will allow us to achieve the main goals of the SCOPSCO project. Altogether, this makes Lake Ohrid a key site of global importance for improving our understanding of Quaternary environmental change in the northern Mediterranean and general triggers of evolutionary events.

Acknowledgements. Financial and logistic support for the SCOPSCO coring campaign was provided by ICDP, the German Ministry of Higher Education and Research, the German Research Foundation, the British Geological Survey, the INGV and CNR (both Italy), and the governments of the republics of Macedonia (FYROM) and Albania. The deep drilling by DOSECC was a huge success, so many thanks to the team.

Edited by: U. Harms

Reviewed by: B. Zolitschka, F. Sylvestre, F. Anselmetti, and H. Lamb
References

Albrecht, C. and Wilke, T.: Lake Ohrid: biodiversity and evolution, Hydrobiologia, 615, 103-140, 2008.

Allen, H. L. and Ocevski, B. T.: Limnological studies in a large, deep, oligotrophic lake (Lake Ohrid, Yugoslavia), Arch. Hydrobiol., 77, 1-21, 1976.

Beck, C., Reyss, J.-L., Leclerc, F., Moreno, E., Feuillet, N., Barrier, L., Beauducel, F., Boudon, G., Clément, V., Deplus, C., Gallou, N., Lebrun, J.-F., Le Friant, A., Nercessian, A., Paterne, M., Pichot, T., and Vidal, C.: Identification of deep subaqueous coseismic scarps through specific coeval sedimentation in Lesser Antilles: implication for seismic hazard, Nat. Hazards Earth Syst. Sci., 12, 1755-1767, doi:10.5194/nhess-12-1755-2012, 2012.

Caron, B., Sulpizio, R., Zanchetta, G., Siani, G., and Santacroce, R.: The Late Holocene to Pleistocene tephrostratigraphic record of Lake Ohrid (Albania), Compt. Rend. Acad. Sc., 342, 453-466, 2010.

Cvetkoska, A., Reed, J. M., and Levkov, Z.: Diatoms as indicators of environmental change in ancient Lake Ohrid during the last glacial-interglacial cycle (ca. $140 \mathrm{ka}$ ), in: Diatom Monographs, Vol. 15, edited by: Witkowski, A., ARG Gartner Verlag, 220 pp., 2012.

Damaschke, M., Sulpizio, R., Zanchetta, G., Wagner, B., Böhm, A., Nowaczyk, N., Rethemeyer, J., and Hilgers, A.: Tephrostratigraphic studies on a sediment core from Lake Prespa in the Balkans, Clim. Past, 9, 267-287, doi:10.5194/cp-9-267-2013, 2013.

Grimm, E. C.: TGView Version 2.0.2, Illinois State Museum, Springfield, 2004.

Hustedt, F.: Diatomeen aus Seen und Quellgebieten der BalkanHalbinsel, Arch. Hydrobiol., 40, 867-973, 1945.

Jurilj, A.: Flora and vegetation of diatoms from Ohrid Lake in Yugoslavia, Yugoslavian Academy of Science, Zagreb [JAZU] 26, 99-190, 1954 (in Serbo-Croatian with English abstract).

Krammer, K. and Lange-Bertalot, H.: Süsswasserflora van Mitteleuropa. Bacillariophyceae. 1. Teil: Naviculaceae (Vol. 2/1), Gustav Fischer Verlag, Stuttgart, 876 pp., 1986.

Krammer, K. and Lange-Bertalot, H.: Süsswasserflora van Mitteleuropa. Bacillariophyceae. 2. Teil: Epithemiaceae, Bacillariaceae, Surirellaceae (Vol. 2/2), Gustav Fischer Verlag, Stuttgart, 596 pp., 1988.

Krammer, K. and Lange-Bertalot, H.: Süsswasserflora van Mitteleuropa. Bacillariophyceae. 3. Teil: Centrales, Fragilariaceae, Eunotiaceae (Vol. 2/3), Gustav Fischer Verlag, Stuttgart, 76 pp., 1991a.

Krammer, K. and Lange-Bertalot, H.: Süsswasserflora van Mitteleuropa. Bacillariophyceae. 4. Teil: Achnanthaceae (Vol. 2/4), Gustav Fischer Verlag, Stuttgart, 437 pp., 1991b.

Kroon, D., Alexander, I., Little, M., Lourens, L. J., Matthewson, A., Robertson, A. H. F., and Sakamoto, T.: Oxygen isotope and sapropel stratigraphy in the eastern Mediterranean during the last 3.2 million years, in: Proceedings of the Ocean Drilling Program, Scientific Results, vol. 160, edited by: Robertson, A. H. F., Emeis, K.-C., Richter, C., and Camerlanghi, A., 181-190, 1998.

Leng, M. J., Baneschi, I., Zanchetta, G., Jex, C. N., Wagner, B., and Vogel, H.: Late Quaternary palaeoenvironmental reconstruction from Lakes Ohrid and Prespa (Macedonia/Albania border) using 
stable isotopes, Biogeosciences, 7, 3109-3122, doi:10.5194/bg7-3109-2010, 2010.

Levkov, Z. and Williams, D. M.: Checklist of diatoms (Bacillariophyta) from Lake Ohrid and Lake Prespa (Macedonia), and their watersheds, Phytotaxa, 45, 1-76, 2012.

Levkov, Z., Krstic, S., Metzeltin, D., and Nakov, T.: Diatoms of Lakes Prespa and Ohrid. About 500 taxa from ancient lake system, Iconographia Diatomologica, 16, ARG Gartner Verlag, 603 pp., 2007.

Lindhorst, K., Grün, M., Krastel, S., and Schwenk, T.: Mass wasting in Lake Ohrid (FYR Macedonia/Albania) - hydroacoustic analysis and its tsunamigenic potential. Submarine mass movements and their consequences, in: Advances in Natural and Technological Hazards Research, 31, edited by: Yamada, Y., Kawamura, K., Ikehara, K., Ogawa, Y., Urgeles, R., Mosher, D., Chaytor, J., and Strasser, M., Springer, 245-253, 2012.

Lindhorst, K., Krastel, S., Reicherter, K., Stipp, M., Wagner, B., and Schwenk, T.: Sedimentary and tectonic evolution of Lake Ohrid (Macedonia/Albania), Basin Res., in press, 2014.

Matter, M., Anselmetti, F. S., Jordanoska, B., Wagner, B., Wessels, M., and Wüest, A.: Carbonate sedimentation and effects of eutrophication observed at the Kališta subaquatic springs in Lake Ohrid (Macedonia), Biogeosciences, 7, 3755-3767, doi:10.5194/bg-7-3755-2010, 2010.

Muço, B., Vaccari, F., Panza, G., and Kuka, N.: Seismic zonation in Albania using a deterministic approach, Tectonophysics, 344, 277-288, 2002.

Mudelsee, M. and Schulz, M.: The Mid-Pleistocene climate transition: onset of $100 \mathrm{ka}$ cycle lags ice volume build-up by $280 \mathrm{ka}$, Earth Planet. Sci. Lett., 151, 117-123, 1997.

Reed, J. M., Cvetkoska, A., Levkov, Z., Vogel, H., and Wagner, B.: The last glacial-interglacial cycle in Lake Ohrid (Macedonia/Albania): testing diatom response to climate, Biogeosciences, 7, 3083-3094, doi:10.5194/bg-7-3083-2010, 2010.

Reicherter, K., Hoffmann, N., Lindhorst, K., Krastel, S., FernandezSteeger, T., Grützner, C., and Wiatr, T.: Active Basins and Neotectonics: Morphotectonics of the Lake Ohrid Basin (FYROM and Albania), Zeitschrift Deutsch. Gesell. Geowiss., 162, 217234, 2011

Schnellmann, M., Anselmetti, F. S., Giardini, D., McKenzie, J. A., and Ward, S.: Prehistoric earthquake history revealed by lacustrine slump deposits, Geology, 30, 1131-1134, 2002.

Sulpizio, R., Zanchetta, G., D’Orazio, M., Vogel, H., and Wagner, B.: Tephrostratigraphy and tephrochronology of lakes Ohrid and Prespa, Balkans, Biogeosciences, 7, 3273-3288, doi:10.5194/bg7-3273-2010, 2010.
Trajanovski, S., Albrecht, C., Schreiber, K., Schultheiß, R., Stadler, T., Benke, M., and Wilke, T.: Testing the spatial and temporal framework of speciation in an ancient lake species flock: the leech genus Dina (Hirudinea: Erpobdellidae) in Lake Ohrid, Biogeosciences, 7, 3387-3402, doi:10.5194/bg-7-3387-2010, 2010.

Tzedakis, P. C., Hooghiemstra, H., and Palike, H.: The last 1.35 million years at Tenaghi Philippon: revised chronostratigraphy and long-term vegetation trends, Quaternary Sci. Rev., 25, 34163430, 2006.

Vogel, H., Wagner, B., Zanchetta, G., Sulpizio, R., and Rosén, P.: A paleoclimate record with tephrochronological age control fort he last glacial-interglacial cycle from Lake Ohrid, Albania and Macedonia, J. Paleolimnol., 44, 295-310, 2010a.

Vogel, H., Zanchetta, G., Sulpizio, R., Wagner, B., and Nowaczyk, N.: A tephrostratigraphic record for the last glacial interglacial cycle from Lake Ohrid, Albania and Macedonia, J. Quat. Sci., 25, 320-338, 2010b.

Wagner, B. and Wilke, T.: Preface "Evolutionary and geological history of the Balkan lakes Ohrid and Prespa", Biogeosciences, 8, 995-998, doi:10.5194/bg-8-995-2011, 2011.

Wagner, B., Reicherter, K., Daut, G., Wessels, M., Matzinger, A., Schwalb, A., Spirkovski, Z., and Sanxhaku, M.: The potential of Lake Ohrid for long-term palaeoenvironmental reconstructions, Palaeogeogr. Palaeoclimat. Palaeoecol., 259, 341-356, 2008.

Wagner, B., Lotter, A. F., Nowaczyk, N., Reed, J. M., Schwalb, A., Sulpizio, R., Valsecchi, V., Wessels, M., and Zanchetta, G.: A 40,000-year record of environmental change from ancient Lake Ohrid (Albania and Macedonia), J. Paleolimnol., 41, 407-430, 2009.

Wagner, B., Vogel, H., Zanchetta, G., and Sulpizio, R.: Environmental change within the Balkan region during the past ca. $50 \mathrm{ka}$ recorded in the sediments from lakes Prespa and Ohrid, Biogeosciences, 7, 3187-3198, doi:10.5194/bg-7-3187-2010, 2010.

Wagner, B., Francke, A., Sulpizio, R., Zanchetta, G., Lindhorst, K., Krastel, S., Vogel, H., Rethemeyer, J., Daut, G., Grazhdani, A., Lushaj, B., and Trajanovski, S.: Possible earthquake trigger for 6th century mass wasting deposit at Lake Ohrid (Macedonia/Albania), Clim. Past, 8, 2069-2078, doi:10.5194/cp-8-2069$2012,2012$. 